\title{
O espectador-transeunte: momentos de suspensão da vida cotidiana
}

The spectator-passerby: suspending moments in daily life

Robson Rosseto ${ }^{1}$

RESUMO

O texto analisa a proposta cênica "Transeuntes", realizada em um terminal de ônibus, que propôs como procedimento cênico o encontro/desvio dos pedestres, interações com os espectadores previamente convidados e dinâmicas estabelecidas com o espaço urbano. Em um ambiente onde concorrem outras ações adjacentes, é solicitada do público a construção dinâmica de interpretação da cena mesclada à vida cotidiana. Desse modo, o espectador, enquanto observante/partícipe, escolhe o que irá ver, realiza cortes e edita, estabelecendo uma percepção seletiva.

Palavras-chaves: Espectador-transeunte. Espaço urbano.

Procedimento cênico.

\section{ABSTRACT}

The present text analyses the scenic presentation entitled "Transeuntes", which took place at a bus terminal and that proposed as a scenic procedure the encounter/dodging of pedestrians, interactions with spectators previously invited and moves established with the urban space. In an environment in which various actions compete, the public is requested to dynamically construct the scene interpretation intertwined with daily life. As a result, the spectator, as a participant/ observer, chooses what she/he will see, cuts and edits, establishing a selective perspective.

Keywords: Spectator-passerby. Urban space. Scenic procedure.
Professor do Curso de Licenciatura em Teatro da Universidade Estadual do Paraná, Campus de Curitiba II. ORCID: http://orcid.org/ ooo0-0002-7905-9819 Contato:

rossetorobson@gmail.com 
Neste texto, proponho-me a analisar a proposta cênica intitulada "Transeuntes" e a relação estabelecida com o público no terminal de ônibus Guadalupe, na cidade de Curitiba. O trabalho foi desenvolvido em uma disciplina, no ano letivo de 2014, com estudantes do Curso de Licenciatura em Teatro da Universidade Estadual do Paraná (UNESPAR), campus de Curitiba II, matéria pela qual sou responsável. Ao longo do texto, denominarei os estudantes universitários de atores/atrizes ou ator/atriz. Na organização dos depoimentos, a identificação dos participantes obedeceu ao seguinte critério: cada um deles foi identificado pelo código $\mathrm{Wn}$ - o caráter $\mathrm{W}$ refere-se ao nome do ator e o índice $n$ à sua posição em uma relação alfabética.

A apresentação cênica analisada, ocorrida em novembro de 2014, envolveu dois perfis de público, o espectador-transeunte e o espectador convidado, momento no qual receberam uma cartografia do espaço denominado de mapa sensitivo e que serviu como guia das cenas. Sensitivo porque o mapa não direcionou o espectador para um trajeto específico, mas a representação gráfica apresentou o espaço geográfico do terminal Guadalupe e identificou pontos estratégicos de atuação dos atores, como, por exemplo, o local do início do acontecimento teatral.

O comportamento humano é o resultado da percepção sensorial associada às emoções, que impulsionam o raciocínio com pensamentos específicos para a capacidade de julgar/optar, conforme declara Damásio:

Certamente não é verdade que a razão opere vantajosamente sem a influência da emoção. Pelo contrário, é provável que a emoção auxilie o raciocínio, em especial quando se trata de questões pessoais e sociais que envolvem risco e conflito. Sugeri que certos níveis de processamento de emoção são provavelmente indicativos do setor do espaço de tomada de decisão onde nosso raciocínio pode operar com máxima eficácia (2000, p. 63).

A autonomia do espectador foi solicitada, lembrando que a decisão para onde ir, qual ator seguir e o que observar foi uma premissa para a promoção de escolhas. Assim, o mapa sensitivo atuou como pistas para acessar a sensorialidade do espectador.

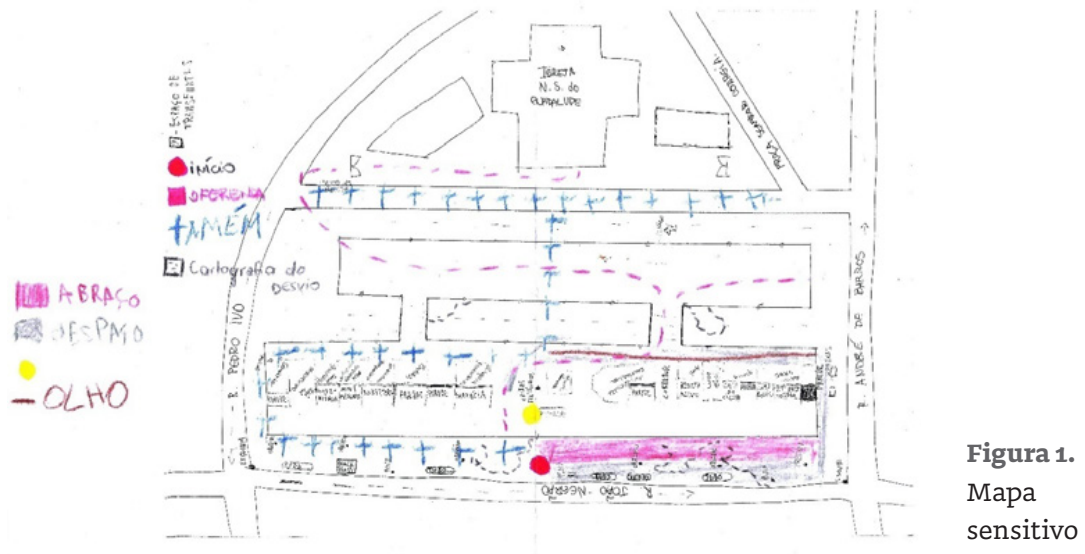


Buscando intensificar as sensações do público, o grupo convidou-os a interpretar as representações e as dimensões simbólicas a partir de um desenho elaborado que apontou possibilidades de leituras do espaço e da produção estética. Essa estratégia teve como proposta sensibilizar os espectadores na articulação entre os diferentes elementos utilizados no espaço cênico. Desse modo, almejou-se a apreensão dos acontecimentos cênicos e do caminho percorrido ao longo de toda a extensão do terminal de ônibus movida pelo envolvimento orgânico.

Os atores, individualmente, chegaram de várias direções e reuniram-se no espaço determinado para o início da proposta. $\mathrm{O}$ encontro entre eles ocorreu por meio do olhar. Em círculo, realizaram exercício para trabalhar a energia do espaço e do corpo potencializadas para a criação: atenção, ritmo, presença e improviso. Em seguida, os atores caminharam e correram em um espaço delimitado, expansão e redução de deslocamento, com movimentos lentos e rápidos. Esse encaminhamento chamou a atenção dos espectadores convidados e, especialmente, dos pedestres do local. Algumas pessoas pararam para observar; outras notaram que algo acontecia, mas continuaram em seus percursos cotidianos.

Destaco que os procedimentos mencionados tangenciam os pressupostos da performance, para a qual o espectador não contempla uma obra como produto acabado: ele é envolvido sensorialmente, afetado o tempo todo pela proposição poética processual que permite estabelecer uma intensa comunicação entre atores e espectadores. A performance, por excelência, é uma arte de fronteira; o teatro, no atual estágio contemporâneo, também se apresenta nesse espaço de fronteira, vindo a se caracterizar gradativamente por seu caráter vulnerável.

O grupo elaborou cenas/intervenções a partir das experiências de interação com o espaço público e com seus moradores. Uma experiência da percepção, dos sentidos, da materialização de encontros. Nessa abordagem, a potência da proposição em pauta é uma forma híbrida de expressão artística localizada em um campo de fronteira entre o teatro e a performance. De acordo com Josette Féral (2008), o teatro foi a arte que mais se beneficiou das aquisições da performance, dado que ele adotou determinados elementos fundadores da performatividade que abalaram o gênero teatral.

A dissolução das fronteiras entre as linguagens artísticas, em fluxos de influências mútuas, propicia ao espectador a oportunidade de sentir a presença, participando, daí, da criação e do desenvolvimento do evento cênico. Dessa forma, atores e espec- 
tadores dividem um espaço de experiências a partir da teatralidade dos atores associada às referências presentes no cotidiano de cada um, em busca de um espaço de intersubjetividade para a concretização de descobertas coletivas.

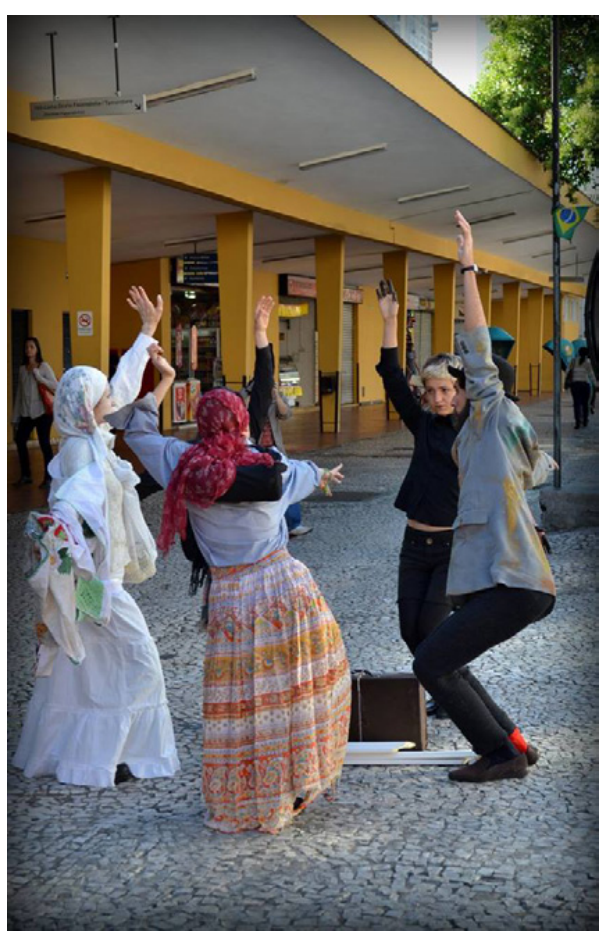

Figura 2.

Cenas iniciais dos atores em

"Transeuntes"2

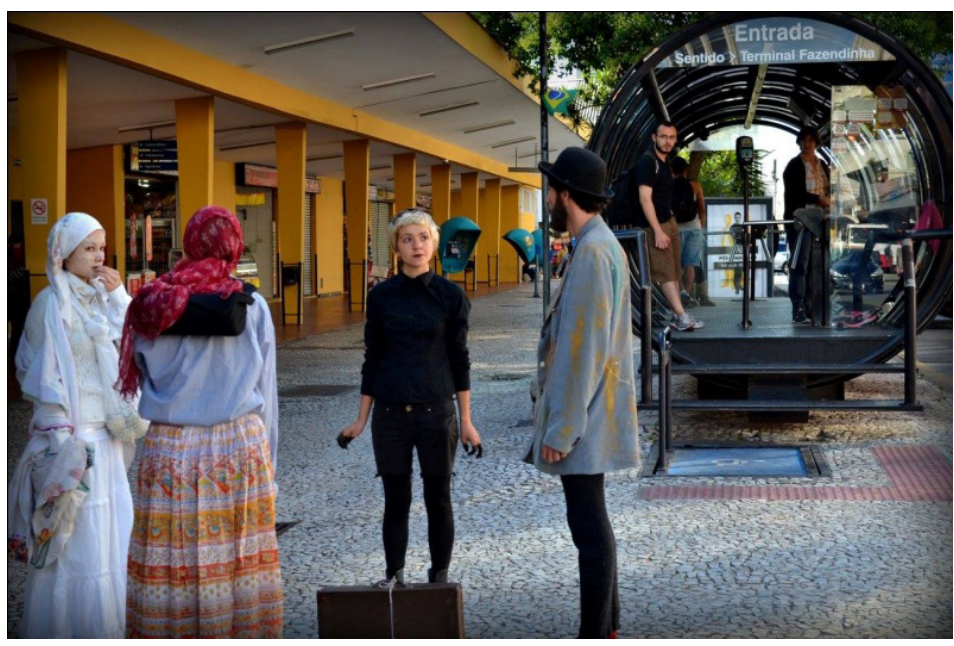

Após a concentração inicial, os atores dispersaram-se individualmente em várias direções no terminal, estratégia que impôs ao público a escolha do papel a ser acompanhado. A opção de seguir um determinado ator coloca-o como responsável pelo que presencia, estabelecendo uma relação igualitária entre cena e espectador. Em outros momentos, quando o espectador-transeunte observou e parou diante da cena, ou mesmo quando essa observação deu-se à distância, da mesma forma, travou-se re-
2.

As fotografias apresentadas neste artigo foram captadas pela fotógrafa Cassiana dos Reis Lopes. 
lação entre ator e espectador e desencadearam-se alterações nos rumos das ações cênicas.

Um diagrama de ações foi previamente ensaiado, mas a composição efetiva ocorreu no instante da apresentação, em interação com os espectadores, os transeuntes, a arquitetura e as situações aleatórias do momento. Acrescento que, na estética analisada, as reações do público são capazes de produzir dramaturgia, sendo que ao ator cabe receber os impulsos para associá-los no percurso narrativo das cenas. Os acontecimentos cênicos tiveram situações coletivas e individuais junto ao fluxo dos pedestres, de forma que os atores misturaram-se aos ocupantes do local. Em determinados momentos, atores e transeuntes confundiram-se.

Essa mistura proposital entre atores e pedestres teve como pressuposto tornar o espaço público mais sensível e causar um desvio poético nos pedestres, cabendo salientar que, assim como as demais metrópoles, gradativamente, a cidade curitibana cedeu espaço a uma paisagem fria, desprovida de incentivos às sensações e às emoções. Essa reflexão reconduz-me a Duarte Júnior, quando este pondera que:

Muito pouco caminhamos por nossas cidades quando desprovidos de um objetivo utilitarista, muito pouco exercitamos os nossos sentidos com sons, cores e odores que não sejam os desagradáveis subprodutos da degradação ambiental urbana [...] E mesmo assim, muito desse caminhar se pauta por regras não sensíveis, mas tão-só imediatistas ou pragmáticas [...] olhar dirigido para o chão ou fixo num ponto infinito, ignorando árvores, flores e pássaros que inundam os arredores de sensibilidade e beleza, bem como ouvidos obliterados por um walk-man ou aparelho eletrônico similar (2003, p. 88).

De fato, no ritmo da caminhada, as pessoas buscam o alívio do estresse e recorrem à utilização de celulares e de dispositivos reprodutores de música, com seus fones de ouvido, para minimizarem a tensão do dia a dia, deixando, muitas vezes, de perceber o seu entorno. Diante desse comportamento comum nas cidades contemporâneas, como ocorreu a intervenção cênica?

Para uma melhor compreensão dos resultados cênicos produzidos no espaço urbano, apresento a seguir a trajetória de cada ator em busca de possibilidades poéticas que extrapolam as ações cotidianas impostas pelo terminal de ônibus e as relações estabelecidas com os espectadores. 

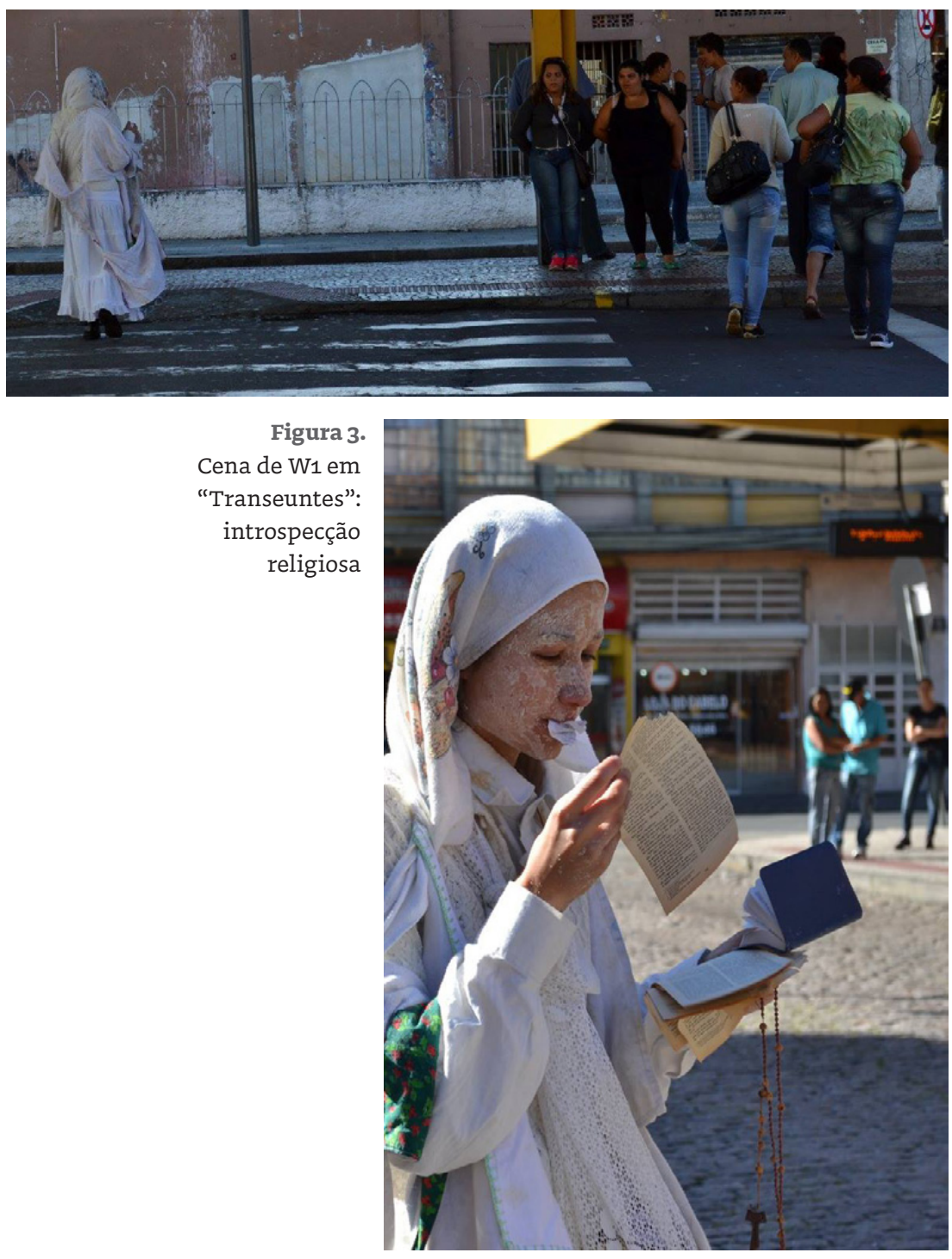

A imagem acima refere-se à atuação de W1 em frente à igreja Nossa Senhora de Guadalupe. Para a construção dessa figura cênica, a atriz inspirou-se nas visitas que realizou à igreja, especialmente na observação de seus frequentadores e nas escritas dos variados cartazes, ofícios, mensagens de agradecimentos - de graças alcançadas - colocados na entrada principal do edifício.

Nas fotografias, é possível notar os pedestres observando a ação cênica. Alguns deles, mesmo à distância, acompanharam com o olhar a caminhada da atriz que, literalmente e metaforicamente, mastigou folhas da Bíblia incorporando-a e tornando-a corpo. Tal como a religião, a atriz imbuiu-se de signos, na ação e na indumentária, que expressaram valores religiosos e socioculturais de fácil assimilação. Abaixo a descrição da cena por uma das espectadoras: 
- Ela pegava farinha do rosto e comia, arrancava papel da bíblia, passava saliva e colava no poste, caminhou lentamente até dentro da igreja, foi muito marcante. Ela entrou na igreja, abriu os braços e saiu correndo. Uma pessoa que estava dentro da igreja a seguiu até a porta pra ver o que iria fazer. Personagem marcante, forte! Quando mexe com religião, as pessoas surtam. Especialmente naquela igreja, quase ponto turístico da cidade (2014).

Com seu modo direto de expor, W1 envolveu o espectador em sua caminhada lenta e silenciosa, ruminando fragmentos de textos considerados sagrados e convidando o público à reflexão sobre as instituições religiosas. No exercício da introspecção, de acordo com Flávio Desgranges (2012), o espectador é convidado a arquitetar o próprio caminho em sua relação com a proposta cênica e na relação desta com a vida social.

Entendo que a ação cênica consistiu em uma experiência propícia às abstrações do espectador, colocando-o em movimento em direção a processos sensíveis. Mas, para que aconteça uma experiência estética, segundo Beatriz Cabral, "[...] é necessária uma interrupção; os choques provocados pelo cotidiano tenso da vida moderna, tal como os traumas para Freud, acarretam uma fratura na vivência e na linguagem, e convidam a uma parada para sentir, perceber, pensar e refletir" (2012, p. 23).

Concordando com a ideia da autora, W1 provocou no espectador mergulhos perceptivos por meio da suspensão do fluxo cotidiano. Ao ser associada à fluidez entre o real e o ficcional, essa experiência aflorou distintas percepções, a partir de uma narrativa sem rígida composição capaz de manter o elemento inusitado nas ações e aceso o jogo de interações. Dessa forma, o desenvolvimento cênico, com qualidades de improvisação, exige do ator a aceitação do imprevisto como uma condição inerente à presença em cena, e do espectador, um grau de proximidade e de participação muito maior em relação ao teatro convencional.

Assim, esse devir proposto nesta experiência cênica manifesta-se como um espaço de imersão sensível do corpo perceptivo, tanto para os atores quanto para os espectadores. A partir de estímulos multissensoriais, a visualidade em ação empregada pela atriz, associada aos ruídos próprios do local, conduz a uma experiência de outra ordem, capaz de propiciar nos transeuntes e nos espectadores convidados encontros poéticos. A atenção é desviada para o que soa imprevisível, para o que é instigante. 


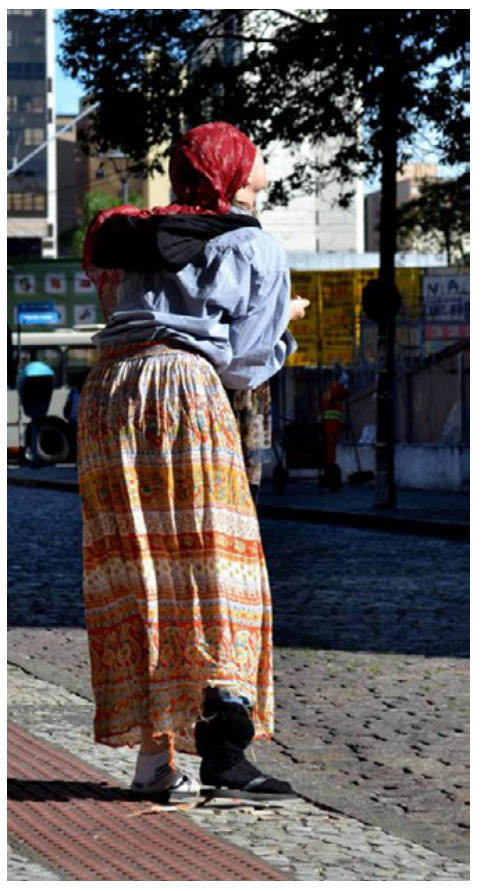

Figura 4. Cena de W2 em "Transeuntes": moradora de rua

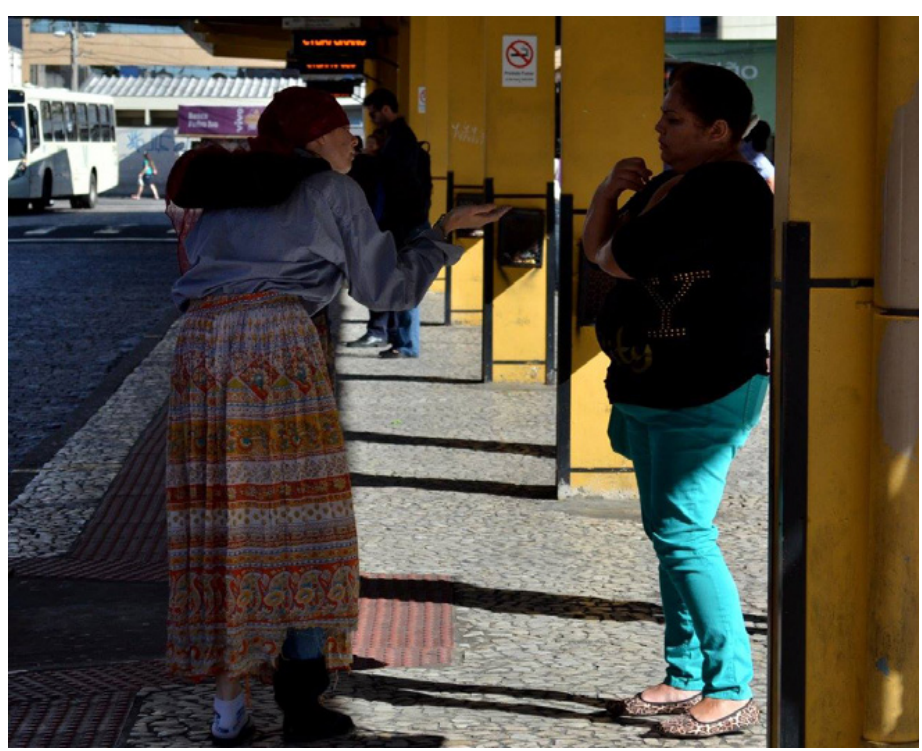

Ao trabalhar especificamente com uma figura comum no meio urbano, de maneira especial no espaço público de um terminal de ônibus, a atriz indumentada como moradora em situação de rua estabelece uma tênue relação com os pedestres/espectadores entre a realidade e a ficção. A artista propôs instigar uma reflexão nos passantes sobre as pessoas que permanecem muitas vezes ocultas no entorno daquele espaço. Ela desvelou características da realidade por meio da relação estabelecida com os espectadores, promovendo uma percepção do contexto social mediada pela interpretação dos sentidos. Neste momento, recorro à fala de um dos espectadores: 
- Olha, isso é pra mostrar os mendigos que vivem aqui, é pra gente pensar! (2014).

Por meio dessa fala, é possível afirmar que a figura cênica alcançou deslocamentos estéticos espelhados em fragmentos do espaço social. A atriz fez menção à história de um vivente daquele espaço borrando as fronteiras entre o universo ficcional e real. As mazelas do cotidiano, recriadas em proposição cênica, podem ser evidenciadas. Em sua caminhada silenciosa, a atriz buscou, com o seu olhar, a comunicação com aquelas pessoas que, encabuladas, desviaram o seu olhar. Essa reação pode ser associada ao estigma do sujeito em situação de rua como socialmente intimidador. Os moradores em situação de rua tornam-se o espelho daquilo que não se quer ser: um sujeito excluído da sociedade.

Muitas vezes, o olhar de W2 expressou apelo-olhar daqueles em situação de exclusão, constrangendo a grande maioria que por ali passava. O fenômeno sensorial foi estimulado, na medida em que o espectador deparou-se com um ser apartado dos princípios da dignidade humana. A narrativa transcende a ação do ator para alcançar a sensibilidade daqueles que assistem à encenação e que com ela se identificam.

Tais aspectos, tensionados por uma dúbia relação - fatos decorrentes da vida cotidiana e da ficção - entrecruzam-se e ampliam o referencial do público em relação aos processos de leitura das produções artísticas. Por outro lado, essa mesma relação exige do ator destreza para administrar situações adversas, uma vez que o risco da rua, a incerteza da vida no momento presente no espaço público, desafia o desenvolvimento da ação cênica. Destaco um fato ocorrido com a atriz e relatado por uma das espectadoras:

- A personagem ofereceu maçã para uma mulher que estava sentada, uma moradora de rua, mas no momento que ela se ajoelhou para entregar a maçã, a mulher entendeu errado e se levantou para dar um soco nela, a atriz se desviou, mas quase acertou ela. Um ator rapidamente se aproximou e ficou por perto. Fiquei pensando, e se a mulher bate na atriz, qual seria a minha reação, interferir ou não interferir? (2014).

O referido episódio coloca o papel de espectador em xeque, convidando-o a sentir e a agir por conta própria diante das situações apresentadas. O público é provocado a assumir uma atitude em presença dos acontecimentos com os quais compartilha a experiência. A iminência do risco, por fundir o lugar da cena com o lugar da observação, promove deslocamentos do estado habitual do público, que deixa de perceber-se somente como espectador 
para visualizar-se como agente de mudança da ação, capaz de colocar-se em cena em decorrência de uma situação inusitada.

Mesmo que nos encontros tenham sido abordadas questões sobre os perigos da rua, reconheço que todos os envolvidos não se prepararam devidamente para se colocar em situações de risco em propostas desenvolvidas em espaço público marcadas pela relação cena/espectador. É precisamente nesse território que reside o estreitamento de laços, de maneira especial com os pedestres que se transformam em plateia. De fato, o ator deve desempenhar o seu papel no mesmo momento em que é obrigado a cuidar dos procedimentos que administram os riscos propostos para as ações cênicas.
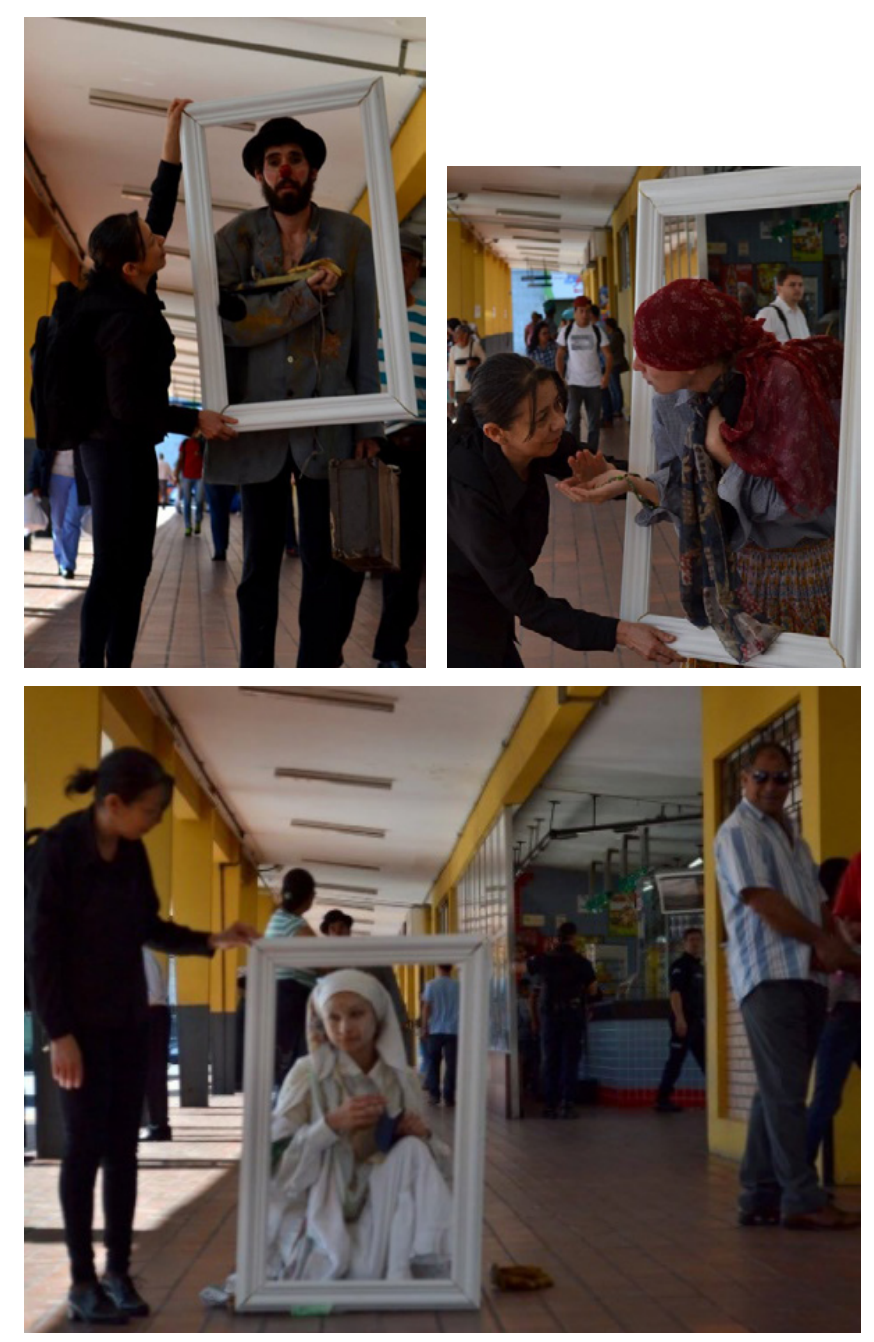

Figura 5. Cena de $\mathrm{W} 3 \mathrm{em}$ "Transeuntes": interferência pela moldura

A moldura, formada por quatro partes, constantemente foi montada e desmontada pela atriz que caminhava pelo espaço; ela, por vezes, parava para montá-la, ação esta seguida de propostas cênicas. A atuação descrita foi repetida inúmeras vezes em locais diferen- 
ciados e explorados pela atriz. $\mathrm{O}$ ato de encaixar as quatro partes causou expectativas às pessoas que permaneciam atentas ao possível desdobramento daquela situação. Em determinados períodos, a atriz autorretratou-se e, em outros, enquadrou os demais atores. Como elemento estranho no espaço, o objeto provocativo criado por W3 direcionou a atenção do público para os emoldurados. Como elemento estranho no espaço, o objeto provocativo criado por W3 direcionou a atenção do público para os emoldurados.

Ao isolar uma figura cênica, um recorte foi realizado, uma intenção foi destacada e provocou o distanciamento do espaço comum, cabendo salientar que a atriz utilizou-se de um figurino de cor preta e dispensou o uso de maquiagem. A partir dos enquadramentos realizados, a artista produziu imagens e proporcionou ao espectador o desenvolvimento da percepção sobre a linha tênue entre a realidade e o campo de atuação. Importa ressaltar que a proposição descrita manteve a atenção da maioria dos pedestres, que pararam para observar e até mesmo fotografar e filmar as cenas.

Em determinados momentos, ao propor uma demarcação nas imagens impostas pela moldura, a atriz apresentou centros visuais, em diferentes níveis construídos e contemplados pela mesma, que se colocou como espectadora da sua própria criação. A moldura recortou o espaço, especificou uma determinada expressão corporal, ação essa que auxiliou no propósito de tornar uma imagem reflexiva para o espectador. Na fala de um espectador abaixo selecionada, lê-se:

- Bonito, é preciso ser artista. Gosta da moldura? Mas vai moldurar o quê? (2014).

Nessa experiência, o espectador sentiu-se à vontade para interagir com a cena, completando a obra e contribuindo à sua maneira. Em conversa posterior, a atriz relatou que, em um determinado momento, a sua atuação aproximou-se de mulheres organizadas em fila na espera do ônibus. Em ação, com seus sentidos aguçados, ela observou que não houve nenhum comentário das mulheres sobre a ação cênica; ainda que olhassem, muitas vezes, demonstravam-se incomodadas e mantinham a postura de quem está diante de uma situação corriqueira.

- Elas esperavam que eu iniciasse uma ação, que falasse algo. Apesar do barulho habitual do terminal, naquele momento tudo ficou em silêncio. Após certo tempo, quando já estava quase insuportável aquela situação, surgiram dois colegas atores, imediatamente elas se olharam aliviadas, e uma delas disse: 'eu sabia que era teatro!' Olhei 
para um lado e para outro da fila e saí também aliviada. Estava tensa ali com aquelas mulheres, a minha respiração ficou diferente, mas fiquei atenta observando e procurando escutar os espectadores. Elas, por sua vez, entraram no mesmo jogo, redobraram a atenção dos próprios gestos vigiando as ações propostas (W3).

A influência mútua não se efetivou de forma direta entre atriz e espectadores, mas as relações estabelecidas entre os olhares promoveram a própria constituição do ato cênico. Os espectadores tiveram a alternativa de aceitar/rejeitar e/ou redefinir suas posturas diante da cena, cuja concepção poética buscou desestabilizar a passividade do público. Cabe, então, nesta fase da pesquisa, relatar o depoimento de um dos espectadores sobre a sua percepção da cena por ele assistida:

As pessoas não param, correm de um lado para o outro, correm para pegar o ônibus. A personagem estava em pé dentro da moldura que estava posicionada no chão, um pedestre tropeçou na moldura, e nem olhou pra trás para ver onde tinha batido. Me questionei, a pessoa passa, bate, não se vira nem pra ver ou pedir desculpa? (2014).

Esta fala assinala que a produção artística apresentou uma nova relação com o tempo daquele contexto e interferiu no ritmo dos passos dos pedestres para seguir a lógica interna do universo poético. A arte contemporânea interroga e induz os apreciadores ao questionamento da arte/vida. De acordo com o mesmo espectador acima mencionado:

Também percebi que muitos pedestres quando se deparavam perante os artistas, diminuíam os passos, olhavam de forma curiosa. A moldura chamou muito a atenção das pessoas. Uma coisa nova pra mim, nunca tinha visto algo parecido, de intervenção (2014).

A proposta lançada pela atriz fomentou a expansão do olhar para além das molduras, rumo ao desenvolvimento de um pensamento crítico-reflexivo, apto a enxergar novos modos de ver e de perceber o mundo, neste caso, o terminal de ônibus. A percepção do lugar é modificada, o olhar transforma-se, as cenas distorcem o espaço urbano, interrompendo o fluxo da vida diária; diferentes possibilidades de interação, assim, são formadas.

No entanto, a interação é um acontecimento singular, o espectador interage em maior ou menor grau com as cenas. Os atores em ação provocam processos de experiência sensível no público: uns são tocados positivamente, outros negativamente; de alguma forma, os passantes são contagiados e provocados pela arte pública. 
Figura 6 Cena de W4 em

"Transeuntes":

clown em ação
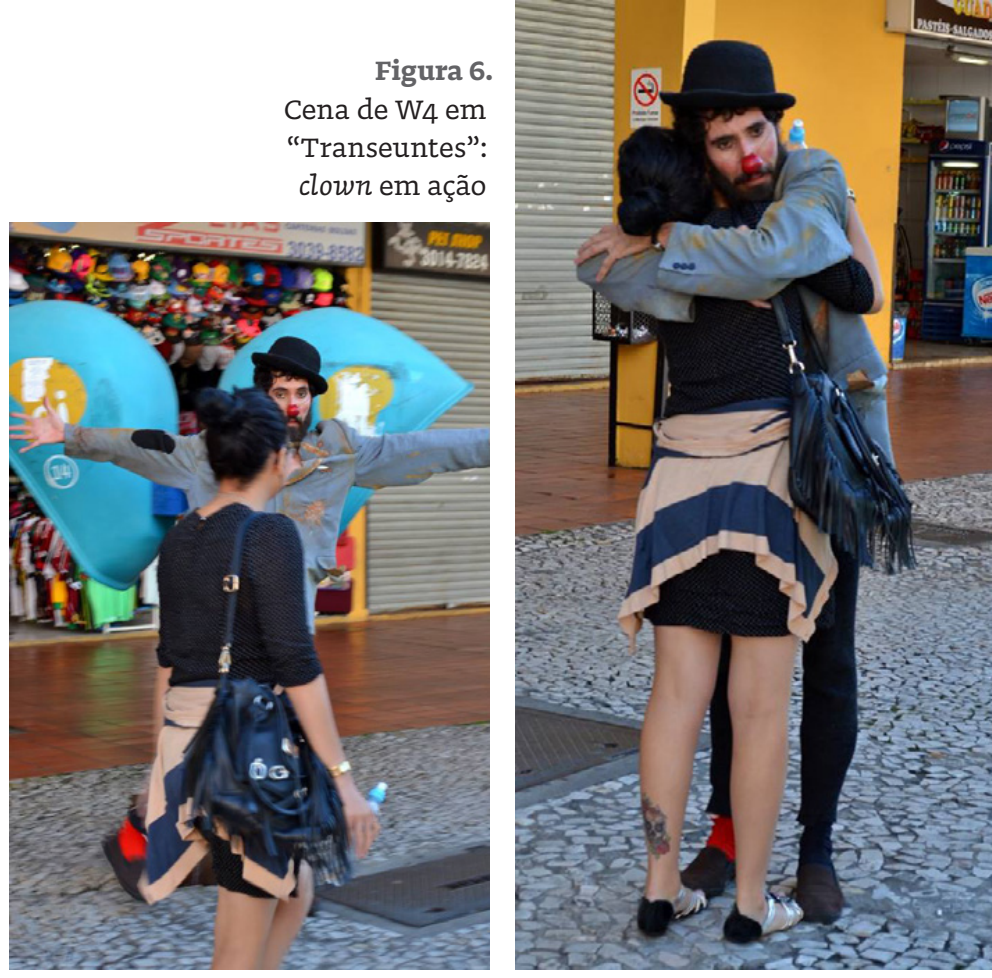

Um clown compôs a proposição cênica. O nariz vermelho configurou a máscara do ator, um dispositivo inquestionável de identificação da linguagem do palhaço. Em geral, esse signo é rapidamente reconhecido pelas pessoas, e essa identidade certifica a fantasia, a ficção, explicita a ocorrência de uma proposição artística. Com a utilização desse recurso, o ator facilitou o contato físico com o pedestre, tal como ilustram as imagens acima expostas, nas quais o clown colocou a espectadora em cena. $\mathrm{O}$ ator declara: "[...] com o acento do clown no nariz, eles parecem esperar algo de você. Porém sei que é ele -o acento-, a convenção, o passaporte que me possibilita transgredir em ações sem que sejamos barrados" (W4).

A partir dessa relação, as habilidades perceptivas do ator são potencializadas no clown, na medida em que ele desenvolve a sua capacidade de resposta quase imediata com a plateia. Dessa maneira,

O clown se alimenta dos estímulos que vêm de seus espectadores, interagindo com eles, numa dinâmica de ação e reação. Essa interação com os espectadores [...] significa uma possibilidade de alteração da sequência das ações do clown. Por isto falamos em improvisação codificada, como nos canovacci da commedia dell'arte, ou seja, uma estrutura geral sobre a qual o clown improvisa com suas ações, que se alteram de acordo com a relação estabelecida com cada espectador ou com seus parceiros (BURNIER, 2009, p. 219).

A comunicação é codificada pelo artista e integrada instantaneamente em suas ações. O clown denuncia, critica, flagra, insinua 
as mazelas da vida, acobertadas com humor e ironia. Segundo as palavras do ator:

Justamente sem a preocupação de ter que fazer rir ou fazer chorar, me coloquei disponível no Terminal Guadalupe [...]. Acredito na força do clown, como um ser que sublinha esse espaço, denuncia a condição de quem ali habita, e grifa esses espaços contidos dentro desse espaço, que é o terminal Guadalupe (W1).

O clown portou-se como morador de rua, caracterizado como um palhaço maltrapilho e desprovido dos cuidados básicos de higiene. Em vários momentos, ele se deitou no chão, e a maleta que levava consigo serviu como encosto de cabeça. Diferentemente da atriz que se colocou como moradora em situação de rua, em função do nariz utilizado, o clown apartou-se da aparência de um andarilho. Ele atraiu a atenção de uma grande parcela dos transeuntes, que o relacionaram à figura de um palhaço, ainda que marcado pela imagem configurada de um ser excluído. Essa composição contribuiu para acionar o potencial reflexivo do público transeunte movido pela elaboração simbólica da ação cênica associada à exclusão de determinadas camadas sociais. Essa constatação é reforçada por uma espectadora:

Ele ficou muito tempo encostado numa parede suja, chão sujo, próximo de uma barraca de camelô, no qual brincou muito com a vendedora deste comércio. $O$ engraçado foi que às vezes as pessoas o confundiam com um morador de rua, homens que aparentemente pareciam estarem bêbados e/ou maltrapilhos ficavam do lado dele, depois de um tempo percebiam que era um ator, e alguns se assustavam (2014).

O teatro pode ser um dispositivo para promover a experimentação poética no espaço urbano e criar novos saberes a partir de experiências estéticas e sensíveis. A produção artística vivenciada, criando efeito de estranhamento do cotidiano, é uma criação que induz o público à participação questionadora. O impacto das situações cênicas alcançadas contribuiu para revelar atitudes e fatos do cotidiano urbano naturalizados na vida em sociedade, abalizada pela injustiça e pela desigualdade social.

A partir de uma escuta mais sensível, o público participou do processo criativo e democrático do fenômeno cênico, a favor do desenvolvimento da leitura proporcionado pela participação ativa das proposições cênicas em um desdobramento da formação do espectador crítico, reflexivo e contextualizador. 


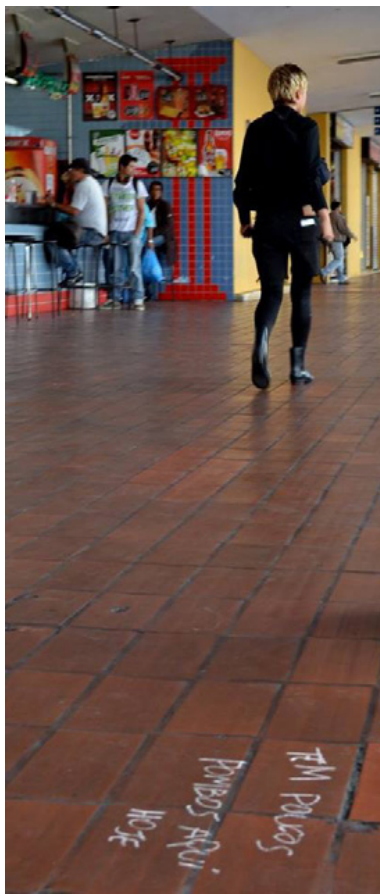

Figura 7. Cena

de W5 em

"Transeuntes": os

pombos dos centros

urbanos

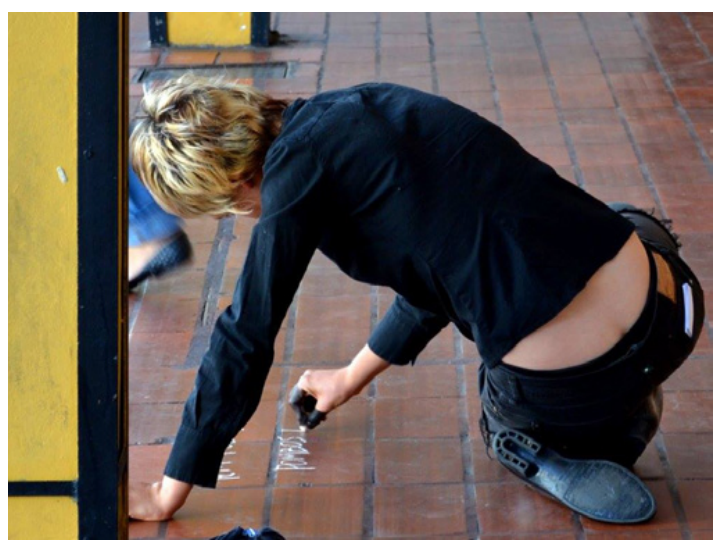

A atriz buscou mapear com escritas de giz no chão os trajetos dos pombos, frequentadores do terminal. A artista selecionou uma ave que vive entre os pedestres da cidade, sendo um dos animais mais visíveis e presentes no cotidiano dos centros urbanos. Por outro lado, esses animais são associados a doenças e, por isso, são comumente denominados "ratos com asas". Ao simular a brincadeira de criança, a artista perseguiu pombos como elemento problematizador.

Na fotografia acima apresentada, a atriz escreveu "tem poucos pombos hoje aqui", e, de fato, naquele dia, um número reduzido de pombos perambulava pela região. Contudo, as marcas literárias foram impressas e promoveu uma atitude investigativa e relacional com o público. Para melhor entendimento, especifico a fala de uma espectadora: "- Não entendi o objetivo dela, entendi as intenções dos outros, mas o dela fiquei me questionando o porquê" (2014).

Nessa perspectiva, a criação artística acionou o espectador ao pensamento crítico e autônomo para a criação e para o questionamento. Ao espectador, cabe o ato de rastrear conexões, pois a estrutura fragmentada das ações cênicas é um convite à imaginação criativa. Contudo, Sílvia Fernandes (2010) ressalta que o artista sabe dos riscos que corre diante do indizível, especialmente em função da subjetividade da cena que, pela sua característica, possibilita que o espectador redimensione e ressignifique os estímulos recebidos.

Nessa dinâmica, o espectador energiza-se de potência criativa para desempenhar pensamentos sobre a tessitura cênica e desenvolve a percepção do processo criativo. Ao fruir uma proposta poética, ele recorre às experiências vividas e emprega a capacidade criativa, 
relacionado-as. Esse impulso inventivo possibilita-lhe lidar com situações novas e inesperadas, internalizando-as.

As cenas realizadas por $\mathrm{W}_{5}$, assim como aquelas elaboradas pelos demais atores envolvidos, adquiriram dimensão de grande palco no trânsito cotidiano. A recepção solicitou dos apreciadores a expansão do olhar ao assumirem o papel de observadores dos acontecimentos cênicos e costumeiros do terminal. Aos poucos, a ampliação do repertório desses se efetiva, visto que "[...] o objeto artístico é que invade o espectador, atingindo-o em seu íntimo, fazendo surgir afetos, sensações, percepções, imagens, entre outras produções, que fazem apelo à experiência pessoal e social do participante" (DESGRANGES, 2012, p. 182).

Dessa forma, o espectador relaciona os acontecimentos de acordo com o seu conhecimento e desenvolve a habilidade para descrever e para analisar convenções poéticas sobre a percepção do trabalho observado. Ao mesmo tempo, desenvolve a capacidade de identificar e comparar a cena observada com outras assistidas anteriormente. Tal aspecto significa que, imbuídos de ideias, de sensações e de hipóteses sobre a experiência artística, os apreciadores produzem conhecimentos acerca da teatralidade contemporânea. Assim, o seu horizonte de expectativas é atravessado e ultrapassado por novos modos de compreender a cena, ao tecer e ampliar as camadas perceptivas em função da imprevisibilidade dos procedimentos de criação improvisacional.
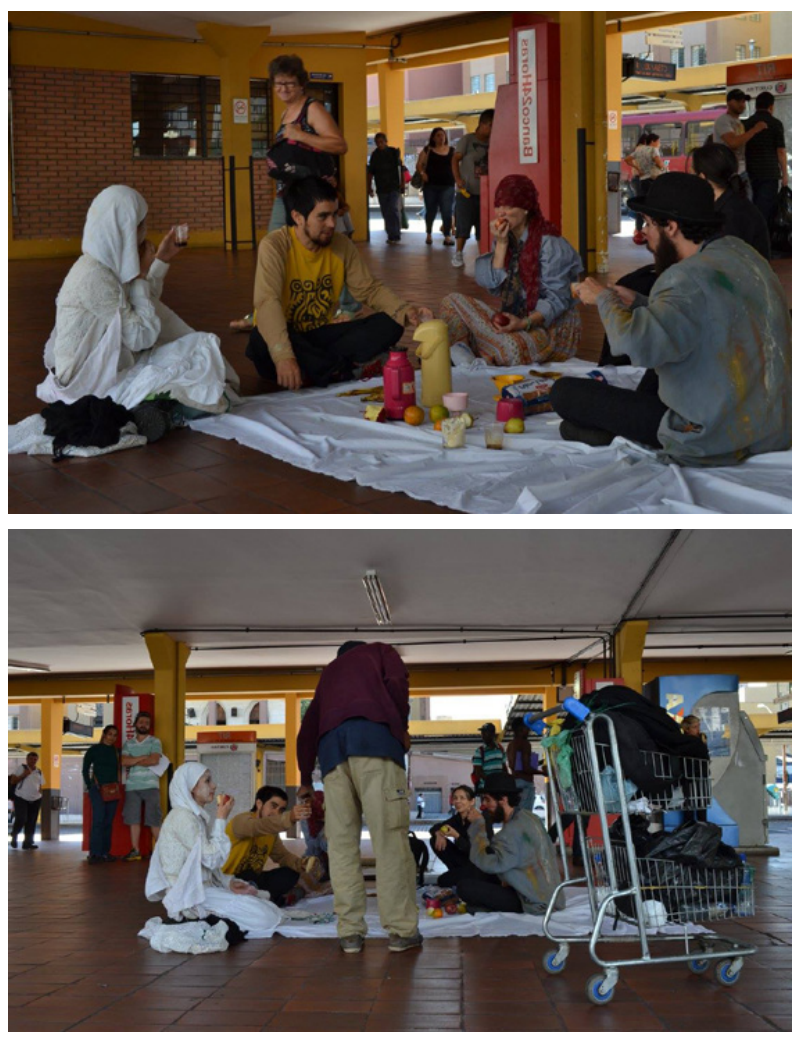

Figura 8.

Cena final dos atores em

"Transeuntes": piquenique do grupo 
No último momento, um piquenique foi realizado com todos os atores reunidos, cada qual com os seus papéis. A partir do ritual do piquenique, a partir da relação corpo e comida, estabeleceram uma simbologia importante na oferta de lazer e de interação social. Os atores coaram café, comeram pão, bolachas e frutas. Em diversos momentos, eles interagiram com as pessoas no entorno, por exemplo, oferecendo alimentos. O piquenique é uma prática que permite a emergência de novas sensibilidades, por meio da experiência dos sentidos, capaz de construir e de reafirmar vínculos sociais.

Pensando em padrões culturais, as refeições em espaços públicos são comuns em distintas comunidades. Contudo, a proposta de uma refeição em um terminal de ônibus inibiu algumas pessoas, que se desviaram da cena pelo inusitado do acontecimento. Com exceção de alguns passantes, que se dispuseram a participar, por exemplo, o espectador de blusa amarela, que, sentado, compartilhou do piquenique. Com o café já coado, um outro pedestre que passava pelo local com um carrinho de supermercado aceitou um copo oferecido pelo mesmo espectador, que se manteve sentado, cabendo destacar a disponibilidade deste, que se demonstrou confortável no jogo cênico.

Na cena descrita acima, os transeuntes-atores interromperam as trajetórias dos transeuntes-pedestres, lembrando que alguns destes a ignoraram enquanto outros olharam de forma furtiva ou assumiram o papel de protagonista do fenômeno cênico, por meio da interação com os atores. Uma das mulheres passantes argumentou o seguinte:

\footnotetext{
- Isso deve ser coisa de teatro, porque pra fazer isso aqui só pode ser teatro, vou fotografar e filmar pra mostrar pro povo da minha família, porque se não é teatro não tem como fazer isso nessa porquice (2014).
}

Após essa fala, o clown ofereceu café à mesma mulher, que rejeitou a bebida por estar a caminho do laboratório para fazer exame de sangue. A investigação de procedimentos cênicos proporcionou uma maior aproximação entre espectador e cena. A relação estabelecida com os observadores ativa camadas sensíveis, facilitadoras de uma aproximação afetiva. Essa relação proporcionou um entrecruzamento entre a ficção e a vida cotidiana; cena e público retroalimentaram-se. De acordo com Claudio Cajaiba:

O mundo, em sua celeridade atual, parece exigir mais dos sentidos, em maior velocidade. As informações, inclusive e especialmente 
na arte, são cada vez mais condensadas, "significadas". [...] Quem se aproxima de uma obra de arte assiste a si próprio e não mais apenas o outro, transforma a estética ali apresentada em autoestética. Atua como um espectador/autor. Cada vez mais se reconhece o ato de fruição como um ato produtivo (2013, p. 122).

Assim sendo, a partir de um processo de reorganização constante, os atores, em coautoria com o público, estabeleceram uma relação de diálogo e compartilharam momentos de improvisação, de criação e de composição de forma espontânea. O pedestre, como coautor da cena, presente e ausente, devido às manifestações do entorno habitual do espaço, vigiou, elegeu, conduziu o tempo e o sentido da representação.

A miscelânea de vozes do ambiente circundante, atrelada às sensações surgidas da relação cena/terminal, exigiu desse habitante da cidade constante ressignificação do espaço. Logo, a geografia da cena absorveu as interferências provocadas pelas características arquitetônicas do local e dos pedestres. Movido por tal concepção, compreendo que a ocupação dos espaços públicos torna-se parte da experiência do espectador, em que a cena teatral é um jogo em aberto, flexível, pois o público escolhe para onde mover-se, elege imagens, lembra de acontecimentos pessoais. De fato, ele compõe, interpreta e estabelece a sua lógica sobre que o vê e sente. A proximidade física dos atores com os espectadores estimulou a habilidade sensível dos envolvidos para organizarem os estímulos recebidos, os quais propiciaram o contato dos transeuntes com experiências poéticas.

A sociedade contemporânea, ao impor uma reorganização dos sentidos em função das novas tecnologias, especialmente as digitais, molda a maneira como o público organiza o pensamento e o conhecimento. A produção cênica, fragmentada, inserida em um espaço tridimensional acústico, preenchido por sons diversos do Terminal Guadalupe, proporcionou uma experiência direta, uma imersão nas sensações. Uma experiência que construiu um espaço sinestésico, travou relações específicas no tempo, no "aqui-agora", um tempo deslocado da ordem cotidiana, da experiência corriqueira.

É preciso ativar os mecanismos sensíveis para perceber o próprio corpo, o corpo do outro e as relações estabelecidas com o espaço, relações a partir das quais esse corpo coloca-se à prova, experimenta e reflete. O artista está em constante processo de aprendizagem; por essa razão, é fundamental que o mesmo compreenda que a percepção é um sistema aberto em permanente troca de informação e que o desenho cênico da sua prática artística congrega e reagrupa todas as influências. 
Na percepção inicial, por meio da visualidade, imediata e sensível, os espectadores convidados e transeuntes captaram as formas do espaço urbano, do conjunto arquitetônico e das proposições artísticas. A percepção visual, assim como os demais sentidos, gradualmente, interage com os fenômenos emocionais e psíquicos, enquanto sensações são produzidas e constituídas no corpo.

Ao mesmo tempo, os espectadores perceberam o ritmo das pessoas, as proporções, os cheiros, o tempo/clima; pela audição, ruídos de veículos, de vozes, dos pássaros, do caminhar; por meio do paladar, o sabor dos alimentos e da bebida ofertados na última cena e por que não, o gosto do vento e da poluição. Aliás, a pele também pode ser considerada um receptor à distância, dado que o corpo é capaz de sentir arrepios, tensões, temperaturas, apresentar alteração na textura da superfície da pele, sem a proximidade de um contato físico. Assim, o conjunto de impressões motivadas pela diversidade do espaço, associado à provocação cênica, promoveram qualidades sensitivas, constituindo encontros de prazer, de efeito estético, ou, mesmo, de sensações desagradáveis.

A partir de pequenos gestos e de ações maiores, a poética concretizada no Terminal Guadalupe provocou sensações no público convidado e nos pedestres, promovendo encontros, desvios e colisões geradoras de momentos de suspensão da vida cotidiana. As interações entre as ações cênicas com o público surpreenderam as expectativas dos envolvidos, com significativas trocas entre artistas e espectadores.

Os atores assumiram o risco de experimentar ao compartilhar uma ação artística em um espaço público, a partir de uma relação não definitiva com a plateia. O jogo cênico elaborado aconteceu de forma intermitente, ao passo que a lógica da poética afetou de forma significativa o caminhar cotidiano do transeunte. O diálogo com a obra artística efetivou-se por intervalos, em contínuo cessar e recomeçar; a atmosfera cênica foi atravessada por possibilidades de reinvenção de forma ousada e instigante. 
BURNIER, Luís Otávio. A arte de ator: da técnica à representação. 2. ed. Campinas: Editora da Unicamp, 2009.

CABRAL, Beatriz Ângela Vieira. Teatro em trânsito: a pedagogia das interações no espaço da cidade. São Paulo: Hucitec, 2012.

CAJAIBA, Claudio. Teorias da recepção: a encenação dos dramas de língua alemã na Bahia. São Paulo: Perspectiva; PPGAC/UFBA, 2013. DAMÁSIO, António. O mistério da consciência: do corpo e das emoções ao conhecimento de si. Trad. de Laura Teixeira Motta. São Paulo: Companhia das Letras, 2000.

DESGRANGES, Flávio. A inversão da olhadela: alterações no ato do espectador teatral. São Paulo: Hucitec, 2012.

DUARTE JÚNIOR, João-Francisco. O sentido dos sentidos: a educação (do) sensível. 2.ed. Curitiba: Criar, 2003.

FÉRAL, Josette. Por uma poética da performatividade: o teatro performativo. Sala Preta, ECA/USP, São Paulo, v.8, p. 197-210, 2008.

FERNANDES, Sílvia. Teatralidades contemporâneas. São Paulo: Perspectiva, 2010. 